\title{
The Impact of Top Management Team Diversity on Firm Performance: A Study of Large Companies in Malaysia
}

\author{
Sreedevi Shammugam, Maran Marimuthu \\ Management and Humanities Department ,32610, Universiti Teknologi PETRONAS, Bandar Seri \\ Iskandar, Perak Darul Ridzuan.
}

\begin{abstract}
The current economic climate has changed the landscape of business dramatically in the perspective of global environment. Hence, in order to respond for the global changes in term of economic, social, politic and technology, organization should enhance the right mix of top management teams (TMT) for current and future progression and growth of the organization. Diversity of top management team plays an important role to determine the performance of the organization. This conceptual paper is to examine the impact of top management team diversity traits on firm performance. The study will adopt quantitative research design with secondary data, for the average of five years. Secondary data mainly involves financial data that will be obtained financial databases such as DATASTREAM based on 200 non- financial large companies in Malaysia. The multiple regression analysis and cross-sectional study will be used to test the hypothesis. Issues surrounding top management team's diversity, upper echelon theories and the mixed findings from previous research are offered as potential avenues for empirical research. Therefore, the line of inquiries needs a fundamental work and empirical analysis using above methodology. The preliminary results leading toward for a better understanding of the factor that explains how top management diversity translates into greater organizational achievements and argues the need to analyse the characteristics of top management teams and their composition more extensively, especially in the context of large companies. This is a cross-sectional study, variables, concepts, constructs and hypotheses will be carefully constructed and developed to meet the objectives of the study. Multivariate analyses will be adopted, and in this regard, panel data analyses using the E- VIEW/STATA statistical software will be used to suit the requirement of considering both cross- sectional and time series data in the analyses.
\end{abstract}

\section{Introduction}

Top management team diversity has become an essential tool that creates a competitive edge in today's corporate world. The leadership with multi skills, unique talent and appropriate abilities become as a main ingredient for the key success of the organization. Despite this, every organization emphasize their top managers used their ultimate capability to formulate efficient strategic for better growth and innovation (Eisenhardt \& Martin, 2000). Therefore, the need of diversity in top management team is necessary for the organization's development and efficient decision-making process. Scholarly comes with different broad definition about diversity terms in the context of research. Diversity is defined as "any attribute that humans 
are likely to use to tell themselves, "has filtered its way up to the highest levels of firms, top management teams (Triandis, Kurowski, \& Gelfand, 1994). As we entered the twenty-first century, diversity term is defined as a group characteristic that reflects the degree to which there are objective or subjective differences among managers (Van Knippenberg \& Schippers, 2007). Generally, diversity of top management teams can be referring to demography factors such as gender, age, tenure, experiences, educational level, race, religion, styles and values which will impact on the decision-making process. This concept is concluded broadly by pioneer scholarly with the introduction of Upper Echelon theory (1984). Upper echelon theory, (Hambrick \& Mason, 1984) posits that the characteristics of top management team which also included the group diversity traits as well and the top management team as a decision maker has an impact on firm performance. Research has shown that diversity can provide positive outcomes for the productivity of the organization ((Murtha, Lenway, \& Bagozzi, 1998); (Bunderson \& Sutcliffe, 2002); ;(E. Randel \& Jaussi, 2003); (Zhang, Lowry, Zhou, \& Fu, 2007)). On another glance of result, few scholarly concluded negative impact of top management team diversity on firm performance (Williams \& O'Reilly III, 1998); (Goll, Sambharya, \& Tucci, 2001); (Berman, West, \& Richter Jr, 2002) ;(Mello \& Ruckes, 2006) ;(Polzer, Caruso, \& Brief, 2008). The mixed results on the outcomes, has opened the path to researcher to further explore diversity traits until it comes to a solid conclusion and close the gap that exists which can help the corporate world to identify the right mixture of diversity of top management team, how it converts to strategic choice and ultimately impact on firm performance. This study will go in line with the inquiry of upper echelon characteristics with the latest update on potential impact of diversity traits on corporate performance with consideration of global diversity and cultural changes as well.

Nevertheless, the research will use average data of five years from large companies (nonfinancial) which was selected from main board of Bursa Saham Malaysia as an evidence of the research. Despite this, diversity traits among managers also change based on the difference of certain elements such as age, tenure, functional background, gender and skills among them. Therefore, the contradictory findings about these traits itself created more question rather than answered by the scholars. A clear knowledge gap exists between each literature and results. Furthermore, the knowledge about right mixture of diversity among manager remain unclear. On the other hand, the real organization also have a different opinion and perception about the diversity and the importance toward the growth of company. Hence, the purpose of this study is to identify the right proposition of diversity traits and how does this trait impact the organization performance by grounding up the overall finding from past research until the current ones for a solid conclusion. This study will also explore the diverse characteristics of top managers and their impact towards large companies by testing multiple industry for year average of five years.

\section{Problem statement}

The core idea of Upper Echelon theory (1984) illustrated that the demographics characteristics of TMT (observable characteristics) such as gender, age, functional background, tenure and educational background can be a better predictor for the firm performance and creating a competitive advantage (Hambrick, Cho, \& Chen, 1996); (Krishnan, Miller, \& Judge, 1997). With the unique experience, capabilities, various demographic factors, TMT is able to judge the selection of appropriate strategy with the resources that firms have accordingly with the climate of global business diversity environments. Even, (Lamberg, Tikkanen, Nokelainen, \& Suur-Inkeroinen, 2009) argued in dynamic business environment and growing competition in the industry leads the 
impact of strategy consistency towards firm survival. Hence, strategy consistency also contributes to the growth of firm performance (Finkelstein \& Hambrick, 1990). On the other hand, TMTs play an important role in the relationship between strategic consistency and organizational performance (Rajagopalan \& Spreitzer, 1996); (Hambrick, Finkelstein, \& Mooney, 2005) because they are the key person and the upper line to run the entire organization.

But the problem is either the existing organization really have a talented or appropriate diversity TMT to carry the battle of strategy for the growth of the organization. For instance, In the year 2014, MAS staff union has faced the dilemma of existing top management not having proper experiences in the aviation industry, hence failed to bring profit for the company, even ${ }^{i 1}$ MAS reported a net loss of RM443million for the first quarter this year compared to RM279million loss in the same quarter last year and 30 MAS pilots resigned their job due to inability to tolerate with the management. Perhaps it's clearly shown that there are several organizations still facing leadership dilemma or top management crisis due to lack of potential characteristics of top management such as group diversity. The research will determine the right mixture of TMT diversity in order to sustain and gain profit for large companies' growth with the empirical evidence.

Growing competition and development of new technology urged the need to revise the characteristics of top managers especially in diversity trait. Furthermore, lack of knowledge and evidences on workforce diversity opens a path to the study to complete the remaining inquiry pertaining to this issue. The past research also concluded that the results on the effect of demographics and job-related diversity on firm performance were manifold and not clearly established (Haas, 2010). Prior literature has been inconclusive with regard to the impact of diversity consistency on organization performance. Even several scholars had done the research on this area, but the research result comes with mixed impact and failed to clarify solid conclusion for the present and future direction for the top management team of the organization. For instance, study of age diversity among TMT, illustrated body of work on this area has not yielded any consistent conclusion about the relationship (Tanikawa, Kim, \& Jung, 2017), some studies have found a positive relationship (Kilduff, Angelmar, \& Mehra, 2000), whereas others have identified negative impact on firm (Ozer, 2010), and non-significant relationship(Nielsen \& Nielsen, 2013).

Besides that, some context factors of conducted diversity studies remain systematically unexplored with regards to their moderating role (Haas, 2010). Perhaps, the previous strategy failed to show the link of mediating role of strategy between diversity TMT and firm performance. The study will give a clear picture about the relationship between dependent variable and independent variable also the how does it impact each other. It is an attempt of ground up from previous literature until present

${ }^{1}$ (://www.thestar.com.my/news/nation/2014/05/16/mas-staff- union-restructure-of-topmanagement/\#vd9) 
issues of TMT diversity and highlighting to main solid conclusion for the future direction and reference of corporate business.

\subsection{Research Questions \& Objective}

\section{Research questions:}

RQ1: What are the appropriate combination of diversity traits within TMT?

RQ2: How does diversity trait within TMT of large companies impact the firm performance?

\section{Research objectives:}

RO1: To determine traits of the diversity among TMT.

RO2: To examine the impact of TMT diversity on firm performance.

\section{Literature review}

Diversity has become an important key to determine the competitive advantage of the organization. It is because the diverse TMT are able to make quality decision for the development of organization in term of selection of choices of strategy. Whereby various opinion and suggestion from different demographic factors and background of managers can lead the firm to succeed in new markets (Agrawal, 2012). Previous studies also concluded that, every different strategy of organization really needs the unique elements such as organizational structure, resources, culture, human capital, talents, and management systems (Porter, 1980)), (Porter, 1985); (Miller, 1992).

When the global economic or domestic economic takes new revolution in business arena, there is a need for the TMT to make a right direction to switch the strategy based on firm resources, demand of consumers and by considering related factors. Therefore, top managers should have diverse talent and abilities to choose the right strategy at the right time from the alternative such as low-cost leadership, innovative orientation, diversification strategy, manufacturing and private brand development (Lin, Chang, \& Dang, 2015). It makes sense as the importance of diverse TMT which has a multi view, different level experiences, broad knowledge and ability to make quality decision to run the goal of the organization. For the past 30 years of research on top management team, starting from the Upper Echelon theory (1984), the new construct about TMT characteristics has appeared again and again without never fully stopping. Its means there are more question about the model itself unexplored and researchers will still continue the efforts to move beyond existing results until the work is complete and satisfies the scholars.

Therefore, the study about TMT diversity also prolongs as even several early scholars have already penetrated the portion but the gap of knowledge on this issue still exists with the presence of globally changing business environment. The positive impact of TMT diversity on firm performance has been revealed by a few researchers (Harrison \& Humphrey, 2010); (Mohammed \& Angell, 2004); (Herrmann \& Datta, 2005); (Shore et al., 2009); (Backes-Gellner \& Veen, 2009); (Bowers, Pharmer, \& Salas, 2000); (Ensley, Pearce, \& Hmieleski, 2006); (Lockwood, 2005); (Leonard, Levine, \& Joshi, 2004);(E. Randel \& Jaussi, 2003); (Zhang et al., 2007); (Tarus \& Aime, 2014); (E. Hoch, 2014). In another research perspective, TMT diversity may lead to the decrease of firm performance (Polzer et 
al., 2008); (Mello \& Ruckes, 2006); (Eisenhardt, 1989) ; (Chen \& MacMillan, 1992). The inconsistency on results opens the need to examine the diversity of climate in the organizations due to the fact that diversity can lead the team of management to possess the full complement of task related characteristics necessary to achieve the desired goals and greater productivity could be achieved (Agrawal, 2012).

Research has also contributed that diversity will increase the morale, higher satisfaction, and higher commitment of workforce and ultimately will impact firm performances (Gilbert, Stead, \& Ivancevich, 1999). The unique talents, innovative credibility, and creative characteristics of TMT will reflect on quality decision to handle battle of management and the ability to adapt with changes of business environment. Perhaps, the more diverse teams will be more non-redundant and non-overlapping information will be shared among the team members (Dahlin, Weingart, \& Hinds, 2005); (Stasser, Stewart, \& Wittenbaum, 1995).

When diversity of top management becomes a topic of discussion, obviously demographics element will become a major factor to determine the degree of diversity and how does it impact the firm performance. Even so, demographics diversity has become an important antecedent to determine the performance of the large firms. Demographics diversity overall explained about age, tenure, functional background, educational and gender differences that may lead to the performance superior. This demographics characteristics concept is hugely accepted and proven by (Hambrick \& Mason, 1984) with the introduction of Upper Echelon theory in arena research. Evidence show that top management teams significantly impact the success of a firm's strategic position (Hambrick \& Finkelstein, 1987); (Hambrick, 2007). For instance, tenure diversity explained the long tenure top managers (Bergh, 2001), going through different cycles and process of the organization, therefore, they accumulated with different experiences, knowledge, skills, managerial ability, excellent in decision-making process because they are well-versed on the external condition and organizational condition as well (Bergh, 2001)); (Hambrick \& Quigley, 2014). Subsequently, scholars such as (Nadolska \& Barkema, 2014), found that tenure heterogeneity has an impact towards firm acquisitions strategy.

However, this contrasts with previous findings that found a negative impact of diversity of TMT on firm performances. It is because when top managers have a diverse tenure, the different interest of goal and different words lead to conflict and strain (Byrne, 1971); (Hambrick \& Quigley, 2014) because the collaboration within team has been affected. Each manager in the team has different abilities and skills, it can be a disadvantage for the development of understanding between group members. Despite this, the top managers who has diverse knowledge and experiences, tend to reject the opinion of other top managers during brainstorming activity. It has been shown that each manager will compare their own self with other managers and can lead to demotivation to complete any group task.

Subsequently, the attraction theory (Byrne, 1971), social identity theory (Tajfel \& Turner, 1986), and self- categorization theory (Turner, Hogg, Oakes, Reicher, \& Wetherell, 1987), are explained and illustrated with examples the negative effects of TMT diversity on firm performance. The issue focused on the TMT members' similarities and differences may be used as a basis for self- categorization (Williams \& O'Reilly III, 1998). This is especially true for readily detected diversity dimensions, such as age and organizational tenure. Categorization processes may produce subgroups within the team and give rise to problematic inter-subgroup relations (Van Knippenberg, De Dreu, \& Homan, 2004), which may cause relationship conflicts (Jehn, Northcraft, \& Neale, 1999); (Pelled, Eisenhardt, \& Xin, 1999). In other word, diverse team members will present different thought worlds (Dougherty, 1992) which will cause the risk of rising value and end conflicts among members 
of the TMT (Jehn et al., 1999); (Gebert, Boerner, \& Kearney, 2006). Due to diversity bring members of TMT difference from various knowledge, background, and skills, the fortune to affect by relationship, a value of culture conflict which will reflect negative firm performance.

Communication becomes another essential point to explain about diversity of top management team. Thus, communication has become a proses to deliver the information. Commonly, communication barrier exists with the presence of diversity among mangers. Meaning to say the diverse characteristics of TMTs reflects to inefficient information sharing among members $(\mathrm{Li}, 2013)$. In other words, it can be said that group characteristics difference has become the reason for interpersonal conflict that occurred (Dahlin et al., 2005). Hence, this barrier leads to managers making poor quality decision toward achieving the goal of the organization due to less collaboration among team while sharing the information.

The pioneer scholars also concluded top managers with high task related diversity positively impact the performance of the organization because their work experiences and education level significantly affect their cognitive structures, knowledge, and competencies (Gunz \& Jalland, 1996). Clearly shown, resource-based diversity gives a clear broad picture to access and makes an effective decision for the development of the organization based on variety of skills, experiences, educational level of TMT. Thus, top executives can overcome conflict (Gerber, Hartmann, Brand, Holsboer-Trachsler, \& Pühse, 2010) to allocate the scarce resources between the strategic contradictions $(\mathrm{Li}, 2013)$. Hence, it is important for the firms to determine the right proposition of diversity among the top managers to achieve a superior performance.

Diversity has become a crucial part to be handled by TMT in order to run the short term or long-term goal of the company. The cognitive mind structure of diverse managers will become a competitive advantage for the firm. It's the compulsory need for the organization to determine the diverse characteristics of TMT for predicting the firm's survival or success in the rapid changing environment. Moreover, the delay to respond on time to the changes of environment may lead to conflict, misfit between the strategy, resistance, delays and inefficient in resource allocations (Kraatz \& Zajac, 2001); (Quigley \& Hambrick, 2012).

Overall, diverse TMTs will tend to have broader picture to choose the best strategy to be formulated based on their various skills, knowledge, experiences and competency. Previous studies on strategic consistency proposed diverse perspectives on the relationship between strategic consistency and organizational performance (Barnett \& Hansen, 1996); (Lamberg et al., 2009); (Delgado-García, La Fuente-Sabaté, \& Manuel, 2010). Even (Hambrick et al., 1996) also underlined that based on the information-processing perspective it suggests that different cognitive model of managers among team will lead to evaluate the choices of strategy and quality decision making process. As a conclusion from the diversity of TMT it is also associated with few factor considerations such as gender, age, tenure, functional background, information sharing, communication, environment, task related diversity or heterogeneity. Therefore, the study will shed the light into top management composition and characteristics especially in term of diversity of senior managers focusing on large nonfinancial companies of Malaysia as evidence to reveal this issue for better understanding for future and present business world. 


\section{Proposition Development}

Based on theoretical and literature arguments, diversity become a determinant factor to predict the success or failure of the organizational. Hence, the proposition developed as bellow:

Proposition 1: TMT Diversity has significant impact on firm performances

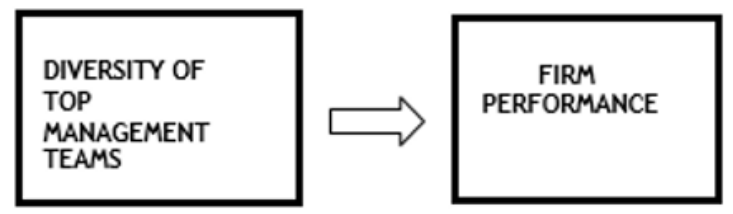

Figure.1: Top management team characteristics from Upper Echelon Theory, Hambrick and Mason (1984)

\section{Methodology}

\subsection{Research Design}

A quantitative research design will be used for the study. The study will examine top 200 largest non-financial companies listed on the Bursa Malaysia Main Board for the period of 5 years from the various sectors. Data sources will be obtained from secondary data. The secondary data refers to an information that has already been collected by someone else and which is available for the researcher (E. Smith \& Smith Jr, 2008). For obtaining the demographic background information, sources of secondary data info include company website, yearbook, bursa saham website, and other sources. On the terms of firm financial performances, data will be collected through secondary data and measured with ROA and Tobin Q.

\subsection{Data collection}

For obtaining the demographic background information, sources of secondary data info included from financial databases. ROA (return on asset) will be used to predict profitability terms. Tobin Q also will be used to study the selected variable relation to firm performance

\subsection{Research Sampling}

A sample of 200 large companies listed on Bursa Saham Malaysia from main board to measure the variables including TMT demographic diversity. Companies will be selected based on market capitalization. This study will adopt judgmental sampling method.

\subsection{Method}

Cross section study method will be used for this study. Time series data from 2012-2016 for selected company will also be used but with taking average of year for the research. Besides that, this study will be using multiple regression analysis to examine the effect or impact of TMT characteristics on firm performance. Finally, the analysis will be using panel data technique. The study measures TMT diversity with a five-item measure, which prior research has indicated that composite indicators of team heterogeneity constructs are good measurements of team outcomes (Campion, Medsker, \& Higgs, 1993); (Van Knippenberg \& 
Schippers, 2007). The five compositions will be age, gender, tenure, functional background and educational background of TMT.

\subsection{Expected Outcomes}

The study will enlighten a set of new findings to improve the Upper Echelon theory based on diversity traits. Preliminary results leading toward the relevance and importance of diversity characteristics among TMT. Beside this, the expected outcomes also mainly to improve the methods and finding with revised version of Upper Echelon model.

\section{Contribution}

Pioneer researchers such as (Nielsen \& Nielsen, 2013), concluded that top management team diversity's impact toward firm performance is still not clearly explained in the literature for the past centuries. Therefore, the study attempts to fill the gap of knowledge and will give a clear understanding about the need of diversity in TMT composition by studying on real large companies practice. Now, we do have Upper Echelon Model 1984, but then it is not in its complete form. This study will be a ground up work to make the model in revised version with revokes deeper the trait of diversity of top management team. Hence, this research will become a blueprint for large organizations to shape their composition of diversity among the top managements.

\section{Conclusion}

Each organization exists to achieve the goal of the company and the key person to run the strategy to achieve the goal will be TMT of the firm. Therefore, the characteristics of TMT will be reflected on the running of the company in short term and long term. Overall the study will close the knowledge gap that exists between TMT behaviour and the selection of strategic choices and firm performances. The study will test each of the variables by using Upper echelon theory as main reference to further explore the TMT characteristics. The study will focus 200 BSKL companies and selected company interview will be conducted. Judgmental sampling is used to make sure the questionnaire answered by top management level. Even from the past 30-year journey of the original upper echelon introduced, plenty of research continues Hambrick's work, but it still has yet to have a solid explanation about the characteristic of TMT impact on firm performance. Overall the study will close the knowledge gap that exists between TMT behaviour and the selection of strategic choices and firm performances. Therefore, the characteristics of TMT will be reflected on the run of the company in short term and long term through the selection of appropriate corporate strategy. Even though managers play multiple roles in business operation, the role of top management team is much important to integrate the internal and external challenges in the decision of strategy choices formation (March \& Simon, 1958); (Andrews, 1971); (Child, 1972) ;(Hambrick \& Mason, 1984); and (Meyer, 1993).

Its cannot be denied that TMT role was important in order to set the mission, formulate the strategic, running the business operation by thinking in different way, measure the fitness of the strategy and coordinate until the input process is converted to outcomes which means company will have a more profitable performance. Recent studies (W. K. Smith \& Tushman, 2005), suggested that the composition of a top management team plays a crucial role in effectively managing contradictions to balance exploration and exploitation. Overall this conceptual paper will enlighten the effect of TMT diversity characteristics on firm performance in the present situation. 


\section{References}

Agrawal, V. (2012). Managing the diversified team: challenges and strategies for improving performance. Team Performance Management: An International Journal, 18(7/8), 384-400.

Andrews, K. R. (1971). The concept of corporate strategy. New York.

Backes-Gellner, U., \& Veen, S. (2009). The impact of aging and age diversity on company performance.

Barnett, W. P., \& Hansen, M. T. (1996). The red queen in organizational evolution. Strategic Management Journal, 17(S1), 139-157.

Bergh, D. D. (2001). Diversification strategy research at a crossroads. The Blackwell handbook of strategic management, 355-376.

Berman, E. M., West, J. P., \& Richter Jr, M. N. (2002). Workplace relations: Friendship patterns and consequences (according to managers). Public Administration Review, 62(2), 217-230.

Bowers, C. A., Pharmer, J. A., \& Salas, E. (2000). When member homogeneity is needed in work teams: A meta-analysis. Small group research, 31(3), 305-327.

Bunderson, J. S., \& Sutcliffe, K. M. (2002). Comparing alternative conceptualizations of functional diversity in management teams: Process and performance effects. Academy of Management Journal, 45(5), 875-893.

Byrne, D. E. (1971). The attraction paradigm (Vol. 11): Academic Pr.

Campion, M. A., Medsker, G. J., \& Higgs, A. C. (1993). Relations between work group characteristics and effectiveness: Implications for designing effective work groups. Personnel psychology, 46(4), 823-847.

Chen, M.-J., \& MacMillan, I. C. (1992). Nonresponse and delayed response to competitive moves: The roles of competitor dependence and action irreversibility. Academy of Management Journal, 35(3), 539-570.

Child, J. (1972). Organizational structure, environment and performance: The role of strategic choice. Sociology, 6(1), 1-22.

Dahlin, K. B., Weingart, L. R., \& Hinds, P. J. (2005). Team diversity and information use. Academy of Management Journal, 48(6), 1107-1123.

Delgado-García, J. B., La Fuente-Sabaté, D., \& Manuel, J. (2010). How do CEO emotions matter? Impact of CEO affective traits on strategic and performance conformity in the Spanish banking industry. Strategic Management Journal, 31(5), 562-574.

Dougherty, D. (1992). Interpretive barriers to successful product innovation in large firms. Organization science, 3(2), 179-202.

E. Hoch, J. (2014). Shared leadership, diversity, and information sharing in teams. Journal of Managerial Psychology, 29(5), 541-564. 
E. Randel, A., \& Jaussi, K. S. (2003). Functional background identity, diversity, and individual performance in cross-functional teams. Academy of Management Journal, 46(6), 763-774.

Eisenhardt, K. M. (1989). Building theories from case study research. Academy of management review, 14(4), 532-550.

Eisenhardt, K. M., \& Martin, J. A. (2000). Dynamic capabilities: what are they? Strategic Management Journal, 1105-1121.

Ensley, M. D., Pearce, C. L., \& Hmieleski, K. M. (2006). The moderating effect of environmental dynamism on the relationship between entrepreneur leadership behavior and new venture performance. Journal of Business Venturing, 21(2), 243-263.

Finkelstein, S., \& Hambrick, D. C. (1990). Top-management-team tenure and organizational outcomes: The moderating role of managerial discretion. Administrative science quarterly, 484-503.

Gebert, D., Boerner, S., \& Kearney, E. (2006). Cross-functionality and innovation in new product development teams: A dilemmatic structure and its consequences for the management of diversity. European Journal of Work and Organizational Psychology, 15(4), 431-458.

Gerber, M., Hartmann, T., Brand, S., Holsboer-Trachsler, E., \& Pühse, U. (2010). The relationship between shift work, perceived stress, sleep and health in Swiss police officers. Journal of Criminal Justice, 38(6), 1167-1175.

Gilbert, J. A., Stead, B. A., \& Ivancevich, J. M. (1999). Diversity management: A new organizational paradigm. Journal of business ethics, 21(1), 61-76.

Goll, I., Sambharya, R. B., \& Tucci, L. A. (2001). Top management team composition, corporate ideology, and firm performance. MIR: Management International Review, 109129.

Gunz, H. P., \& Jalland, R. M. (1996). Managerial careers and business strategies. Academy of management review, 21(3), 718-756.

Haas, H. (2010). How can we explain mixed effects of diversity on team performance? A review with emphasis on context. Equality, Diversity and Inclusion: An International Journal, 29(5), 458-490.

Hambrick, D. C. (2007). Upper echelons theory: An update. Academy of management review, 32(2), 334-343.

Hambrick, D. C., Cho, T. S., \& Chen, M.-J. (1996). The influence of top management team heterogeneity on firms' competitive moves. Administrative science quarterly, 659-684.

Hambrick, D. C., \& Finkelstein, S. (1987). Managerial discretion: A bridge between polar views of organizational outcomes. Research in organizational behavior.

Hambrick, D. C., Finkelstein, S., \& Mooney, A. C. (2005). Executive job demands: New insights for explaining strategic decisions and leader behaviors. Academy of management review, 30(3), 472-491. 
Hambrick, D. C., \& Mason, P. A. (1984). Upper echelons: The organization as a reflection of its top managers. Academy of management review, 9(2), 193-206.

Hambrick, D. C., \& Quigley, T. J. (2014). Toward more accurate contextualization of the CEO effect on firm performance. Strategic Management Journal, 35(4), 473-491.

Harrison, D. A., \& Humphrey, S. E. (2010). Designing for diversity or diversity for design? Tasks, interdependence, and within-unit differences at work. Journal of organizational behavior, 31(2-3), 328-337.

Herrmann, P., \& Datta, D. K. (2005). Relationships between top management team characteristics and international diversification: An empirical investigation. British Journal of Management, 16(1), 69-78.

Jehn, K. A., Northcraft, G. B., \& Neale, M. A. (1999). Why differences make a difference: A field study of diversity, conflict and performance in workgroups. Administrative science quarterly, 44(4), 741-763.

Kilduff, M., Angelmar, R., \& Mehra, A. (2000). Top management-team diversity and firm performance: Examining the role of cognitions. Organization science, 11(1), 21-34.

Kraatz, M. S., \& Zajac, E. J. (2001). How organizational resources affect strategic change and performance in turbulent environments: Theory and evidence. Organization science, 12(5), 632-657.

Krishnan, H. A., Miller, A., \& Judge, W. Q. (1997). Diversification and top management team complementarity: Is performance improved by merging similar or dissimilar teams? Strategic Management Journal, 361-374.

Lamberg, J. A., Tikkanen, H., Nokelainen, T., \& Suur-Inkeroinen, H. (2009). Competitive dynamics, strategic consistency, and organizational survival. Strategic Management Journal, 30(1), 45-60.

Leonard, J. S., Levine, D. I., \& Joshi, A. (2004). Do birds of a feather shop together? The effects on performance of employees' similarity with one another and with customers. Journal of organizational behavior, 25(6), 731-754.

Li, C.-R. (2013). How top management team diversity fosters organizational ambidexterity: The role of social capital among top executives. Journal of Organizational Change Management, 26(5), 874-896.

Lin, C.-S., Chang, R.-Y., \& Dang, V. T. (2015). An integrated model to explain how corporate social responsibility affects corporate financial performance. Sustainability, 7(7), 8292-8311.

Lockwood, N. (2005). Workplace diversity: Leveraging the power of difference for competitive advantage: Society for Human Resource Management.

March, J. G., \& Simon, H. A. (1958). Organizations.

Mello, A. S., \& Ruckes, M. E. (2006). Team composition. The Journal of Business, 79(3), 1019-1039.

Meyer, M. W. (1993). Organizational Design. Explorations in economic sociology, 249. 
Miller, D. (1992). The generic strategy trap. Journal of business Strategy, 13(1), 37-41.

Mohammed, S., \& Angell, L. C. (2004). Surface-and deep-level diversity in workgroups: Examining the moderating effects of team orientation and team process on relationship conflict. Journal of organizational behavior, 25(8), 1015-1039.

Murtha, T. P., Lenway, S. A., \& Bagozzi, R. P. (1998). Global mind-sets and cognitive shift in a complex multinational corporation. Strategic Management Journal, 97-114.

Nadolska, A., \& Barkema, H. G. (2014). Good learners: How top management teams affect the success and frequency of acquisitions. Strategic Management Journal, 35(10), 14831507.

Nielsen, B. B., \& Nielsen, S. (2013). Top management team nationality diversity and firm performance: A multilevel study. Strategic Management Journal, 34(3), 373-382.

Ozer, M. (2010). Top management teams and corporate political activity: Do top management teams have influence on corporate political activity? Journal of Business Research, 63(11), 1196-1201.

Pelled, L. H., Eisenhardt, K. M., \& Xin, K. R. (1999). Exploring the black box: An analysis of work group diversity, conflict and performance. Administrative science quarterly, 44(1), $1-28$.

Polzer, J. T., Caruso, H. M., \& Brief, A. (2008). Identity negotiation processes amidst diversity. Diversity at work, 89-126.

Porter, M. E. (1980). Competitive strategy: Techniques for analyzing industries and competition. New York, 300, 28.

Porter, M. E. (1985). Competitive advantage: creating and sustaining superior performance. 1985. In: New York: Free Press.

Quigley, T. J., \& Hambrick, D. C. (2012). When the former CEO stays on as board chair: Effects on successor discretion, strategic change, and performance. Strategic Management Journal, 33(7), 834-859.

Rajagopalan, N., \& Spreitzer, G. M. (1996). TOWARDS A THEORY OF STRATEGIC CHANGE: A MULTI-LENS PERSPECTIVE AND INTEGRATIVE FRAMEWORK. Paper presented at the Academy of Management Proceedings.

Shore, L. M., Chung-Herrera, B. G., Dean, M. A., Ehrhart, K. H., Jung, D. I., Randel, A. E., $\&$ Singh, G. (2009). Diversity in organizations: Where are we now and where are we going? Human resource management review, 19(2), 117-133.

Smith, E., \& Smith Jr, J. (2008). Using secondary data in educational and social research: McGraw-Hill Education (UK).

Smith, W. K., \& Tushman, M. L. (2005). Managing strategic contradictions: A top management model for managing innovation streams. Organization science, 16(5), 522-536.

Stasser, G., Stewart, D. D., \& Wittenbaum, G. M. (1995). Expert roles and information exchange during discussion: The importance of knowing who knows what. Journal of experimental social psychology, 31(3), 244-265. 
Tajfel, H., \& Turner, J. (1986). The social identity theory of intergroup behavior. In S. Worchel \& WG Austin (Eds.), Psychology of intergroup relations: 7-24. Chicago: NelsonHall.

Tanikawa, T., Kim, S., \& Jung, Y. (2017). Top management team diversity and firm performance: exploring a function of age. Team Performance Management: An International Journal, 23(3/4), 156-170.

Tarus, D. K., \& Aime, F. (2014). Board demographic diversity, firm performance and strategic change. Management Research Review, 37(12), 1110.

Triandis, H. C., Kurowski, L. L., \& Gelfand, M. J. (1994). Workplace diversity.

Turner, J. C., Hogg, M. A., Oakes, P. J., Reicher, S. D., \& Wetherell, M. S. (1987). Rediscovering the social group: A self-categorization theory: Basil Blackwell.

Van Knippenberg, D., De Dreu, C. K., \& Homan, A. C. (2004). Work group diversity and group performance: an integrative model and research agenda. Journal of applied Psychology, 89(6), 1008.

Van Knippenberg, D., \& Schippers, M. C. (2007). Work group diversity. Annu. Rev. Psychol., 58, 515-541.

Williams, K. Y., \& O'Reilly III, C. A. (1998). DEMOGRAPHY AND. Research in organizational behavior, 20, 77-140.

Zhang, D., Lowry, P. B., Zhou, L., \& Fu, X. (2007). The impact of individualismcollectivism, social presence, and group diversity on group decision making under majority influence. Journal of Management Information Systems, 23(4), 53-80. 